DOI 10.37882/2223-2982.2021.06.10

\title{
ИСТОРИКО-ЭКОЛОГИЧЕСКИЙ АСПЕКТ РАЗВИТИЯ ТЕКСТИЛЬНОЙ ПРОМЫШЛЕННОСТИ В РОССИИ ВО ВТОРОЙ ПОЛОВИНЕ ХІХ - НАЧАЛЕ ХХ В. (НА ПРИМЕРЕ ВЛАДИМИРСКОЙ ГУБЕРНИИ)
}

\section{HISTORICAL AND ENVIRONMENTAL PERSPECTIVE OF THE DEVELOPMENT OF THE TEXTILE INDUSTRY IN RUSSIA IN THE SECOND HALF OF THE NINETEENTH CENTURY AND IN THE BEGINNING OF THE TWENTIETH CENTURY (THE CASE OF VLADIMIR PROVINCE) \\ T. Golubkina \\ M. Smirnova}

Summary: The article deals with the relationship between the technological development of the textile industry of Vladimir province in the second half of the XIX and early XX century and the emergence of environmental problems. The article considers the main factors and features of the development of textile production in the region, the sources and types of water pollution by the factory industry, investigates the main measures and difficulties in the field of environmental policy.

Keywords: textile industry, ecological history, Vladimir province, environmental policy.

\author{
Голубкина Татьяна Михайловна \\ К.и.н., доцент, Владимирский государственный \\ университет им. А.Г. и Н.Г. Столетовых \\ golubkina@vtsnet.ru \\ Смирнова Мария Сергеевна \\ К.филол.н., дочент, Владимирский филиал Российской \\ академии народного хозяйства и государственной \\ службы при Президенте РФ \\ ms01052014@yandex.ru
}

Аннотация: В статье рассматриваются вопросы взаимосвязи технологического развития текстильной отрасли Владимирской губернии во второй половине XIX -начале XX в. и возникновения экологических проблем. Рассмотрены основные факторы и особенности развития текстильного производства в регионе, исследуются источники и виды загрязнения водных ресурсов фабрично-заводской промышленностью, а также основные мероприятия и трудности в области природоохранной политики.

Ключевые слова: текстильная промышленность, экологическая история, Владимирская губерния, природоохранная политика.

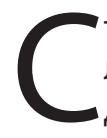

труктура и динамика развития отдельных отраслей отечественной текстильной промышленности давно стали предметом пристального внимания экономистов, инженеров, историков, философов техники и других специалистов. Вместе с тем, все более актуальным становится исследование промышленной эволюции в контексте взаимодействия общества и природы, что предполагает анализ основных проблем истории промышленности и технологии именно в экологическом, природоохранном аспекте.

Одним из традиционных центров текстильного производства дореволюционной России была Владимирская губерния. Формирование местного промышленного профиля и географии текстильной отрасли имело свои особенности. Скудность почв при высокой плотности населения, острая проблема малоземелья порождали стремление крестьян к дополнительному заработку. Важным фактором развития промысловой деятельности стала близость Москвы, которая была обширным рынком сбыта. Уже в XVII в. Владимирский край становится центром холщового промысла, в конце XVIII - начале XIX в. широкое распространение получает изготовление на ручных ткацких станках простых и общедоступных тогда хлопчатобумажных тканей (нанки, холстинки, китайки, парусинки), возникает особое ситце-набивное производство по холсту масляными красками. Уничтожение центров текстильной промышленности Московского промышленного региона в ходе Отечественной войны 1812 г. благоприятно повлияло на провинциальное производство, снизив конкуренцию. Дальнейшему успеху отрасли способствовало строительство в 70-90-е гг. XIX в. железных дорог, связавших Иваново-Вознесенск, Тейково и Александров с Москвой, Нижним Новгородом и пристанями Верхней Волги.

В конце XIX - начале XX вв. текстильная промышленность переживала этап своего подъема: в 1890 г. Владимирская губерния, 13 фабрик которой располагали 878162 веретенами, 12917 рабочими и вырабатывали изделий на 27,2 млн. рублей, занимала третье место в стране, [9, с. 89], что нашло отражение в закрепившемся 
тогда названии «Ситцевый край». Текстильная отрасль была представлена обработкой льна, шерсти, производством шелковых тканей, однако особое место в текстильной промышленности занимала хлопчатобумажная, на долю которой приходилось более 2/3 всех мануфактур отрасли $[12$, с. 8].

В изучаемый период во Владимирской губернии сложилось несколько текстильных центров, важнейшим из которых стал Шуйский уезд, где функционировал ряд фабрик, отличавшихся высокой производительностью труда и рентабельностью. Крупнейшим индустриальным центром уезда стал город Иваново-Вознесенск, текстильные фабрики находились также в селах Тейково и Кохма. Производственный профиль Шуйского уезда составляли ситце-печатание, крашение, беление и отделка ситцев, а также бумагопрядение и ткачество миткалей. Второе по значению место занимал Александровский уезд с хлопчатобумажными фабриками в селах Карабаново, Струнино, Дубна и Константиновское. Важную роль здесь играли крупные мануфактуры купцов Барановых, специализировавшиеся на пунцово-красильном производстве. Среди предприятий Покровского уезда настоящим промышленным гигантом была Никольская мануфактура Морозовых. Вязниковский уезд являлся центром обработки льна.

Необходимым условием зарождения и развития промышленных предприятий текстильной отрасли стала развитая речная сеть Владимирской губернии. С давних пор река Клязьма с ее притоками являлась дешевой и удобной транспортной артерией и служила торговой дорогой на Волгу, а позднее - и на Нижегородскую ярмарку. Для промышленников Шуйского уезда исключительное экономическое значение имела река Теза, судоходство по которой удалось восстановить в 1837 г. [13, c. XV]. С развитием мануфактурной стадии текстильные фабрики превратились также и в крупнейших потребителей водных ресурсов. В изучаемый период вода использовалась ими для замачивания сырья, его очистки и промывки, отбеливания, крашения и отделки тканей и для других технологических процессов [14]. Свойства воды в некоторых реках, например р. Уводи, на берегах которой и вырос Иваново-Вознесенск, идеально подходили для красильного производства [6, с. 136]. По мере роста масштабов производства, объемы потребляемой воды становились все более и более значительными. Так, например, Куваевская ситценабивная мануфактура в Ивано-Вознесенске тратила 268168750 ведер воды в год [3].

Во второй половине XIX - начале XX в. практически вся вода после применения в производстве вновь оказывалась в естественных источниках. Происходило это в результате несовершенства технологий и очистных механизмов. Немаловажное значение часто имела халат- ность собственников и рабочих предприятий. Сточные воды отрасли представляли собой сложную физико-химическую систему, содержащую в своем составе разнообразные виды красителей, минеральные соли, органические вещества. В конце XIX в., когда качественные немецкие красители сменились менее технологичными местными, проблема приобрела еще большую остроту. «Россия, по-видимому, не изжила неправильной точки зрения на реки как на бездонные клоачные ямы», - отмечал современник [1, с. 38]. Для предотвращения загрязнения окружающей среды сточными фабричными водами мировой и отечественной наукой был разработан ряд технологий. Химические технологии предполагали собой очистку воды известью и хлористым железом, использовались также способы Бурова, Шмита и другие. Однако уже в XIX в. была признана бесперспективность имеющихся способов химической очистки сточных вод, а самым эффективным стал считаться биологический метод.

Этот метод представлял собой систему орошения, которая активно использовалась в южных губерниях Российской империи. Наиболее часто это внедрялось в сахарной промышленности. Механические способы очистки предполагали фильтрацию сточных вод через песок [7, с. 219]. Применение подобного метода встречалось в нескольких промышленных заведениях Владимирской губернии. На красильной фабрике Бартена в Шуйском уезде отработанные воды, прежде чем попасть в речку Сибирянку, проходили предварительно через ряд отстойников и соломенных фильтров, после чего обесцвечивались. Три колодца с фильтрами по последнему слову науки были устроены на красильной фабрике Симанина в селе Ставрове и некоторых других предприятиях. И хотя этот способ не требовал больших материальных затрат от фабриканта, но даже и он использовался скорее в виде исключения. Подавляющее большинство предпочитали сбрасывать отработанные воды в реки без всякой очистки. «Способ этот, по своей простоте и удобству настолько популярен, что им пользуются даже в тех случаях, когда при фабрике существуют требуемые колодцы», - отмечал владимирский гидролог Н.И. Дубровский [4, с. 14].

Производственные сточные воды составляли, однако, лишь часть загрязнений, попадавших в реки. Специализированных систем канализования промышленных предприятий не существовало, и сточные воды отводились совместно с коммунальными нечистотами фабричных бараков и бытовых построек (бани, прачечные и пр.). «Все нечистоты с фабрики и фабричного двора удаляются через канавы в поле и затем в р. Клязьму. Из отбельного заведения все общие отбросы направляются в одну общую канаву, имеющую направление в р. Клязьму, на фабричном дворе, в ткацком отделении, повсюду проложены подземные водосточные трубы, 
служащие очистке двора от всех нечистот, спускаемых в эти трубы», - так описывал систему отведения стоков полотняно-ткацкой и отбельной фабрики С.И. Сенькова В г. Вязники санитарный врач С.В. Любимский [10, с. 139]. Учитывая значительную численность населения фабрично-заводских поселков, можно полагать, что количество коммунальных сбросов, загрязняющих почву и открытые водоемы, достигало значительных размеров.

О том, что многие из рек Владимирской губернии, начиная с Клязьмы, были уже тогда сильно загрязнены, много писала местная периодическая печать. И все же Клязьма, подобно другим крупным рекам, благодаря своему сравнительному полноводью и большой скорости течения, самоочищалась. Хуже обстояло дело с мелководными реками, одной из которых стала Уводь, снабжавшая водой большинство текстильных предприятий «Русского Манчестера». Владимирская периодика неоднократно обращала внимание общественности на многочисленные факты гибели ихтиофауны в Уводи, полную непригодность речной и даже колодезной воды для употребления, распространение эпидемий. Присутствовала и эстетическая составляющая - вода издавала зловонный запах, окрестное население не могло плавать по реке и купаться в ней.

Сообщения газет подтверждали данные химического анализа и биологических исследований, проводившихся во Владимирской губернии. Так, в 1903 г. Н.И. Дубровский по поручению «Владимирского общества любителей естествознания» и по просьбе председателя Ковровской управы провел обследование Уводи и ее притока Вязьмы. Через каждые 5 верст, а также непосредственно после каждой фабрики, из Уводи были взяты пробы воды. Гидролог использовал также статистические данные, собранные путем опроса населения. Результаты 287 химических анализов были сведены в таблицы и диаграммы. Не вдаваясь в химические и биологические подробности, отметим, что пробы обнаружили изменение химического состава воды, наличие таких веществ, как сероводород, метан, фосфор, водород, соли тяжелых ядовитых металлов. Причем кривые окисляемости, аммиака, сухого остатка резко поднимались именно при вступлении в район Иваново-Вознесенска. Вода имела желтоватый или красноватый оттенок, была «семицветной» от плавающей на ее поверхности нефти и краски. Начиная от первой Ивановской фабрики, из реки исчезла не только рыба, но и водоросли. «Общий вид еще более неприглядный. Берега черные, на них навалены отбросы. Вонь невыносимая. Рабочие жалуются на головные боли», - сообщал Н.И. Дубровский. Кроме того, исследование выявило, что вплоть до самого устья река не успевала освободиться от внесенных в нее в Иваново и Кохме нечистот [4, с.14-27].

Исследование вод в самых «неблагополучных» Ков- ровском и Шуйском уездах было продолжено летом 1904 г. В статистическом отношении исследование показало следующую картину: из 54 образцов речной воды 12 (22\%) оказались удовлетворительными, «подозрительными» - 7 (13\%), неудовлетворительными - 35 (65\%). Также автор показал, что загрязнение речной системы не только било по здоровью населения, но и наносило и значительный экономический ущерб крестьянским хозяйствам, приводя в негодность покосы, снижая качество заливных лугов и доходность рыболовного промысла [5, с. 98]. Проведенное исследование помимо научного имело и практическое значение. Оно не только способствовало привлечению внимания общественности к вопросу о защите водных богатств губернии от промышленных загрязнений, но и поставило этот вопрос на повестку дня органов местного самоуправления.

На государственном уровне очистке сточных вод промышленных предприятий в России уделялось внимание, начиная с 1885 года, когда был утвержден «Устав промышленный». Однако, согласно действующему законодательству, большинство вопросов местного хозяйства, в числе которых и проблемы, касавшиеся водоснабжения, были возложены на органы местного самоуправления. Тема загрязнения окружающей среды фабрично-заводскими предприятиями неоднократно обсуждалась на заседаниях городских дум и уездных земств. Так, власти Иваново-Вознесенска в 1874 г. рассматривали вопрос об очищении дна Уводи от накопившихся нечистот [2, с. 40-41]. Александровское уездное земское собрание в течение трех лет (1893-1895 гг.) рассматривало вопрос о порче воды фабриками и заводами [4, с. 12].

Обсуждение этих вопросов на заседаниях земских учреждений не только способствовало осознанию масштабности и серьезности проблемы промышленного загрязнения среды, но и привело к практическому результату: Владимирское губернское земское собрание стало одним из немногих земств, которым в 1892-1893 гг. были составлены «Обязательные санитарные постановления для уездного населения Владимирской губернии». Согласно этим постановлениям, запрещались спуски грязных вод, химических продуктов и вообще всех вредных отбросов производства в реки, ручьи, пруды, которые использовались населением для своих нужд. Промывные воды, спускаемые в низины, овраги и болота, также должны были быть предварительно обезврежены [8, с.372-381]. Санитарные постановления, содержащие аналогичные требования по отношению к сточным водам, издавались также губернским по фабричным делам присутствием [11, с. 12-14].

Вместе с тем, технический регламент качества и характеристик сточных вод, равно как и критерии определения пригодности воды для дальнейшего употребления в постановления не вошли. Кроме того, постановления 
страдали и еще одним не менее существенным недостатком: предписывая устранение вреда от загрязнений, они не давали никаких конкретных указаний для практического выполнения этих требований, а отсутствие надежной системы контроля усугублялось мягкостью наказания. Так, за порчу воды в местах, где ее использовали жители, виновные подвергались аресту не свыше 7 дней или денежному взысканию не более 25 рублей [11, с. 120]. Тем самым, интересы предпринимателей ставились выше задач охраны природы.

Таким образом, общий промышленный подъем кон- ца XIX - начала XX в. охватил и текстильную отрасль. Высокая концентрация текстильных производств и рост промысловой деятельности во Владимирской губернии обусловили зарождение региональных экологических проблем. Вместе с тем, очевидно, что природоохранная деятельность государства и органов местного самоуправления не носила целенаправленного и систематического характера, а ничтожные денежные штрафы, выплачиваемые заводами и фабриками, не служили сколько-нибудь достаточным стимулом для принятия природоохранных мер со стороны самих предпринимателей.

\section{ЛИТЕРАТУРА}

1. Брудастов И. Гидротехническая деятельность в губернии в прошедшем и настоящем времени и ее перспективы в будущем // Наше хозяйство. 1924. № 3-4. С. 34-40.

2. Гарелин Я.П. Город Иваново-Вознесенск или бывшее село Иваново и Вознесенский посад (Владимирской губернии): В 2 ч. / Сост. Я.П. Гарелин. Шуя: ЛитоТипография Я.И. Борисоглебского, 1885. Ч. 2. 225 с.

3. Гулидов А.Ю. Дело об очистке реки Уводи // Борисовский сборник/ Отв. ред. В.В. Возилов. Вып. 1. Иваново: Издательский дом «Референт», 2009. C. 74-77.

4. Дубровский Н. К вопросу о загрязнении Владимирских рек//Труды Владимирского общества любителей естествознания. Т. 1. Вып. ІІ. Владимир: Типолитография губернской земской управы, 1904. С. 10-27.

5. Дубровский Н. Питьевые воды Владимирской губернии. Волости Кохомская, Ивановская и Якиманская Шуйского уезда и некоторые местности Владимирского уезда // Труды Владимирского общества любителей естествознания. Т. 1. Вып. ІІ. Владимир: Типолитография губернской земской управы, 1904. C. 31-99.

6. Историко-статистические сведения о некоторых местностях Владимирской губернии. Владимир: Типография Губернского правления, 1901. 188 с.

7. Клешнина И.И. История решения вопросов очистки промышленно-бытовых промышленнобытовых сточных вод (пример очистки сточных вод ОАО «Нижнекамскнефтехим») // Вестник Казанского технологического университета. 2014. Т. 17. № 23. С. 218-223.

8. Обязательные санитарные постановления для уездного населения Владимирской губернии // Вестник Владимирского губернского земства. 1893 . № 7. Владимир-на-Клязьме: Типолитография губернской земской управы, 1893. С. 372-381.

9. Пажитнов К.А. Очерки истории текстильной промышленности дореволюционной России. М.: Издательство Академии Наук СССР, 1958. 423 с.

10. Санитарное исследование фабричных заведений Вязниковского уезда. Произведено по распоряжению Владимирского губернского земствского собрания врачем С.В. Любимским. Владимир на Клязьме: Типо-Литография Губернской земской управы, 1884. 244 с.

11. Сборник положений, правил, разъяснений и обязательных постановлений о надзоре за заведениями фабричной промышленности, изданный Владимирским Губернским по фабричным делам присутствием. Владимир-на-Клязьме: Типография губернского правления, 1894. 126 с.

12. Свирский В.Ф. Фабрики, заводы и прочие промышленные заведения Владимирской губернии. Владимир на Клязьме: Типо-Литография Губернской земской управы, 1890.68 с.

13. Списки населенных мест Российской империи. VI. Владимирская губерния. СПб.: Издано Центральным статистическим комитетом министерства внутренних дел, 1863. 283 с.

14. Цейтлин Е.А. Очерки истории текстильной техники. М.: Издательство АН СССР, 1940. 466 с. 